FORUM

Submitted 05.02.2013. Approved 22.08.2013

Evaluated by double blind review. Scientific Editors: Mário Aquino Alves, Ezequiel Reficco and Juan Arroyo

DOI: http://dx.doi.org/10.1590/So034-759020140102

\title{
A NEW APPROACH FOR MEASURING CORPORATE REPUTATION
}

\author{
Uma nova abordagem para mensurar a reputação corporativa
}

Un nuevo abordaje para evaluar la reputación corporativa

\begin{abstract}
This study describes the concept of corporate reputation and reviews some of the major points that exist when it comes to measuring it. It thus suggests a new index for measurement and its advantages and disadvantages are pointed out. The consistency of the seven key variables for the collecting indicator is described by the results of a factor analysis and correlations. Finally, the indicator is put to test by gathering the perception of corporate reputation of 1500 individuals for 69 companies belonging to 15 different industrial sectors, in Peru. The results indicate that the proposed index variables are not necessarily of greatest interest to the study sample in which companies have a better performance. Also greater memorial companies aren't necessarily those that enjoy a greater corporate reputation. Managerial implications for the organizations in the process of managing and monitoring the dimensions involved of this key asset are also referenced.
\end{abstract}

KEYWORDS / Corporate Reputation, stakeholder's perceptions, Corporate Social Responsibility, reputation management, corporate social initiatives.

\section{RESUMEN}

La investigación describe el concepto de Reputación Corporativa y pasa revista a algunas de las principales observaciones que existen a la hora de medirla. Se propone luego un nuevo indice para su medición y se señalan ventajas y desventajas del mismo. La coherencia de las siete variables clave que recoge el indicador se describe mediante los resultados de un análisis factorial y de tests de correlaciones. Por último, se pone a prueba el indicador al recoger la percepción de reputación corporativa de 1500 individuos para 69 empresas pertenecientes a 15 sectores industriales distintos, en Perú. Los resultados indican que no necesariamente las variables del índice propuesto que son de mayor interés para la muestra del estudio son aquellas en las cuales las empresas tienen un mejor desempeño. Asimismo, las empresas de mayor recordación tampoco son necesariamente las que gozan de una mayor reputación corporativa. Implicaciones gerenciales para las organizaciones en la gestión y monitoreo de las dimensiones de este activo clave también son referenciadas.

PALABRAS-CLAVE / Reputación Corporativa, percepciones de las partes interesadas, responsabilidad social corporativa, gestión de la reputación, responsabilidad social.

percy.marquina@pucp.pe Director of the CENTRUM Business

School, Pontificia Universidad

Católica del Perú, Lima - Perú

ROLANDO ARELLANO BAHAMONDE rjarellano@arellanomarketing.com Master in Marketing, IAE de Grenoble, Université Pierre-MendèsFrance, Grenoble - France

\section{ISABELLE VELASQUEZ BELLIDO} isabelle.velasquezbellido@postgrad. mbs.ac.uk

Researcher, CENTRUM Católica Business School, Pontificia Universidad Católica del Perú, Lima - Perú

\section{RESUMO}

Este estudo descreve o conceito de reputação corporativa e analisa alguns dos principais elementos relativos à sua mensuração. Sugere-se um novo índice para a mensuração e suas vantagens e desvantagens são indicadas. A consistência das sete variáveis-chave para o indicador é descrita pelos resultados de uma análise fatorial e suas correlações. 0 indicador é testado por meio de um levantamento da percepção de 1500 indivíduos sobre a reputação corporativa de 69 empresas pertencentes a 15 setores industriais peruanos diferentes. Os resultados indicam que as variáveis propostas para o índice não são necessariamente de maior interesse para que as empresas tenham melhor desempenho. Ademais, as empresas mais conhecidas não são necessariamente aquelas que desfrutam de maior reputação corporativa. Também são citadas as implicações gerenciais envolvidas no processo de administrar e monitorar as dimensões da reputação corporativa.

PALAVRAS-CHAVE | Reputação corporativa, percepções das partes interessadas, responsabilidade social corporativa, gestão da reputação, iniciativas sociais corporativas. 


\section{INTRODUCTION}

For many years now, especially over the last decade, there has been growing interest in defining and measuring corporate reputation in business and academia. The loss of confidence by investors, analysts, clients and other stakeholders has been acknowledged to be potentially devastating for the sustainability of business in the long term (Resnick, 2004); hence the importance of monitoring and managing this intangible asset appropriately.

An organization's reputation is a reflection of how it is regarded by its multiple stakeholders. Its reputational stance can help the organization obtain trust and credibility in society, which will assist in the achievement of its objectives and goals (Baur \& Schmitz, 2011, Mahon \& Wartick, 2003, Roper \& Fill, 2012). The role of business in society has evolved over the years, from being mainly concerned with profit for shareholders to a stakeholder and community approach with a focus on corporate social responsibility (Covey \& Brown, 2001, Steyn, 2003). With this broadening of responsibilities comes a more multidimensional reputation, and the age of globalisation has made it harder for organizations to be the sole managers. Less privacy and increasing accountability have made a more proactive strategy necessary from organizations to prevent damages to its image and reputation (Roper \& Fill, 2012). A solid reputation among their different stakeholders is something all brands need to take care of, given that it can help organizations when having to deal with hostile environments; it is an important source of goodwill when dealing with crises; it can be a competitive advantage and allows the organization to attract the best employees and ensures their loyalty (Foreman \& Argenti, 2005).
This paper reviews several studies engaged with corporate reputation in a logical sequence driven by some keys questions about this concept: What is it? Why is it important? How is it managed? This is followed by the introduction of a new index as an alternative instrument for measuring corporate reputation: the Consumer Reputation Index (CRI). The proposed index seeks to measure corporate reputation in regards to seven key variables. The final objective is to aid organizations in the process of managing and monitoring the dimensions involved in this key intangible asset.

\section{DEFINITION OF CORPORATE REPUTATION}

Academic interest in corporate reputation has grown out of branding literature in the 1990 s and earlier work on organizational identity (Martin, Beaumont, Doig, \& Pate, 2005). Corporate reputation is a construct closely linked to stakeholder theory: it has been mostly conceptualized in academic literature, since Fombrun (1996), as a perceptual representation or assessment of the firm by its different constituents (Winn, McDonald, \& Zietsma, 2008, Bromley, 2000, Meijer \& Kleinnijenhuis, 2006) and its different social expectations or corporate personality traits that people attribute to companies (Berens \& Van Riel, 2004). It is probably convenient to start by establishing a general framework for the corporate reputation construct given that, as Barnett, Jermier \& Lafferty (2006, v. 9, p. 28) pointed out, "[concepts such as] identity, image and reputation are still often used interchangeably". Walker (2010) summarized the differences found between the terms in a systematic review of corporate reputation literature over a 27 -year period using multiple management disciplines, as shown in Exhibit 1.

\section{Exhibit 1 Differences between organizational identity, organizational image, and corporate reputation}

\begin{tabular}{l|l|l|l}
\hline & Organizational Identity & Organizational Image & Corporate Reputation \\
\hline $\begin{array}{l}\text { Stakeholders: Internal or } \\
\text { external }\end{array}$ & Internal & External & Internal and external \\
\hline Perceptions: Actual or desired & Actual & Desired & Actual \\
\hline $\begin{array}{l}\text { Emanating from inside or outside } \\
\text { the firm }\end{array}$ & Inside & Inside & Inside and outside \\
\hline $\begin{array}{l}\text { Positive or negative perception } \\
\text { of the firm possible }\end{array}$ & Positive or negative & Positive & Positive or negative \\
\hline $\begin{array}{l}\text { Relevant question } \\
\text { “Who / what do we } \\
\text { believe we are? }\end{array}$ & $\begin{array}{l}\text { "What / who do we want others } \\
\text { to think we are?” }\end{array}$ & $\begin{array}{l}\text { "What are we seen } \\
\text { to be? }\end{array}$
\end{tabular}

Source: Walker, 2010. 
According to Exhibit 1, given that corporate reputation is built on external and internal stakeholders' current perceptions it is possible for it to be either positive or negative. In this sense, it can be differentiated from concepts such as identity and organizational image, which are conceptualized only from one type of stakeholder (identity for internal stakeholders and image for external ones). Corporate reputation can be studied as a function of both image and identity (Tkalac \& Vercic, 2007). Identity is built inside the company, based on the organization's culture. It consists of current practices, history, values and behaviour (Melewar, Karaosmanoglu \& Paterson, 2005). Image is built inside external stakeholders' minds; it refers to their temporal impression of the organization shaped by direct or indirect experiences: how they perceive the organization's identity at a given point in time (Balmer \& Greyser, 2002, Melewar, Karaosmanoglu \& Paterson, 2005, Hatch \& Schultz, 1997). Corporate reputation is built over time (historical component), which gives the concept a relatively more stable and enduring nature than image. Both concepts are interrelated, where corporate reputation has been conceptualised as the accumulation of images over the years (Gotsi \& Wilson, 2001, Mahon, 2002). It should be noted that corporate reputation could be influenced by changes taking place in its social environment, or by strategies carried out by the same organization or its competitors (García de los Salmones, Herrero \& Rodríguez del Bosque, 2005).

As a dynamic concept, corporate reputation develops as information about the organization's activities and achievements is spread out, and interactions take place between the organization and its stakeholders (suppliers, salesmen, competitors, clients, investors, employees and local communities). Different stakeholders may then have different perceptions regarding the organization, based on their differing contexts and interpretation of the information received: an organization may have, at the same time, a good reputation among its stockholders and one not so good among its employees (Fombrun, 1996, Bromley, 2000, Mahon, 2002, Prado, 2008). Organizations are not wholly in control of the information about them that exists outside the firm's boundaries. Many stakeholders base their opinions without ever having any direct interaction with the company, through third-party sources (e.g. the media and opinion leaders). Therefore, organizations face an important challenge when it comes to managing their own reputation: reputation may be influenced by a variety of outside sources besides communication and signalling from inside the company (Brown, Dacin, Pratt \& Whetten, 2006, Einwiller, Carron \& Korn, 2010). Schultz, Hatch, \& Larsen (2000, p. 1) state, “organizations [now] compete based on their ability to express who they are and what they stand for".
Thus, reputation can be thought of as the global perception or evaluation that constituents hold regarding a company's performance and attributes. It is a collective phenomenon that comprises both cognitive and affective dimensions, and develops over time (Bromley, 2000, Karaosmanoglu \& Melewar, 2006). Corporate reputation takes place when compared to a certain standard (can be against other firms in the industry) to determine the organization's relative position and general appeal (Deephouse \& Carter, 2005) helping it measure its performance from an outside perception (Sarstedt \& Schloderer, 2010).

\section{BENEFITS OF CORPORATE REPUTATION}

Corporate reputation has been studied under several disciplinary perspectives: institutional theory, financial theory, economic theory, organizational behaviour theory, etc. For the purposes of explaining why a positive corporate reputation brings benefits to the organization, we will focus firstly on the three theories most commonly referred in recent years: signalling theory, strategy theory, and the resource-based value theory. According to signalling theory (Smith, Smith, \& Wang, 2010, Walker, 2010) reputation can be thought of as an informative sign about the organization's likely behaviour and quality performance. This increases the public's confidence in the organization's products and services, and the investor's trust in the organization's performance. Corporate reputation could be seen as “depict[ing] the firm's ability to render valued results to stakeholders" (Fombrun, Gardberg \& Sever, 2000, v. 7, p. 243). Thus, it helps reduce uncertainty, which allows reducing transaction costs. That's why, from a strategic point of view, corporate reputation has been an asset of great value for organizations when attempting to differentiate from the rest of the industry and creating potential barriers to entry for potential competitors. Also, a positive reputation is a strategic resource for building credibility and support among different stakeholders (Melewar, 2003). Resource-based value theory classifies corporate reputation as a valuable and distinctive intangible resource that can help the organization obtain competitive advantage. One of the reasons corporate reputation is hard to imitate in the short term is the time it takes to develop the construct and the complex stakeholder relationships built in the process (Mahon, 2002, Martínez \& Olmedo, 2009).

Fombrun \& Van Riel (1997, v. 1, p. 128) have defined corporate reputation as an intangible asset because they consider it "rare, difficult to imitate or replicate, complex and multidimensional, which needs a lot of time to accumulate, specific, 
difficult to manipulate by the firm, with no limits in its use and does not depreciate with use". Also, Barney (1991) suggests that reputation fulfils the qualities required by a strategic resource, given that: (i) it is valuable, it has relevance; (ii) it is a scarce resource among real or potential competitors; (iii) it has a specific character (difficult to imitate) for its social complexity; and (iv) it does not have equivalent strategic substitutes. Gardberg \& Fombrun (2002) add that reputation is an increasingly important factor for creating and maintaining competitive advantages due to four tendencies in the business environment: (a) global penetration of markets; (b) congestion and fragmentation of media; (c) appearance of more communicative markets; (d) commodification (conversion to mass products) of industries and their products

Hence, research has linked corporate reputation with the improvement of both the financial results and the company's value; a favourable corporate reputation is more likely to be associated with superior performance (Chernatony, 1999, Baden-Fuller \& Hwee, 2001, Roberts \& Dowling, 2002, Kitchen \& Laurence, 2003, Berens, 2004, Brammer \& Millington, 2005). In concrete terms, the main benefits of a strong corporate reputation could be listed as follows:

- Improving the consumer's perception of the quality of products or services (which allows to charge premium prices): sale increases and positive world-ofmouth

- Improving the capacity of hiring and retaining qualified personnel in corporations.

- $\quad$ Raising the morale of employees and therefore productivity.

- Protecting the value of the enterprise by diminishing the impact of scrutinizing, crisis and/or competitive attacks.

- $\quad$ Preceding and helping international expansion, not only in terms of market penetration but also in preparing the scenery in key communities and facilitating alliances.

- $\quad$ Attracting a greater number of investors (good credibility): rise of market value (EBITDA) and diminishing risks for the organization.

- $\quad$ Differencing the company from its competitors and establishing better market positioning.

- Allowing access to cheaper capital.

A positive corporate reputation also enhances the competitiveness of the organization, though in an indirect way, through the assured quality of the supply of products and ser- vices (Awang \& Jusoff, 2009) and awareness of its social responsibility activities (Porter \& Kramer, 2006). Given the rise of the so-called "ethical consumer" (escalating requirements from stakeholders for transparency and ethical business practices) and the increased pressure on organizations to attain international standards on this area due to media and NGO scrutiny, corporate social responsibility (ethical marketing practices, environment) has become a key factor for corporate reputation (Pruzan, 2001, Melewar, Karaosmanoglu, \& Paterson, 2005). A positive reputation for socially responsible practices is a necessary condition for maintaining an organization's license to operate. Legitimacy nowadays comes not only from financial aspects but from social and environmental ones too. Organizations nowadays need more than ever to maintain harmonious relationships with their different stakeholders so as to sustain a competitive economic performance (Huang, 2008).

More recently, Fombrun (2011) has spoken of a new "economy of reputation", where society will be highly connected through networks and organizations will operate in an ecosystem of permanent influence from their groups of interest. In this analytical scheme, given that information would not be symmetrically distributed between the networks, "trust" and "relationships" become vital assets. Thus, traditional and non-traditional means of communication, like social networks, may influence and mobilize both market and society with their particular interpretation of organizational performance. This is how a circular relationship emerges between society and organizations, where support of the former for the latter will depend on the favourable perception they have of each other. Likewise, the performance of the organization will benefit from the support that it may generate among its different stakeholders.

Therefore, in this reputational economy, value is created when intangible assets are properly used. This is why recent studies reveal that the person responsible for managing intangibles should progressively hold a more relevant position in the strategic decision-making at organizations (European Communication Monitor, 2011, p. 62).

\section{STRATEGIC MANAGEMENT OF REPUTATION}

All the above mentioned should naturally and logically lead to organizations considering how they can manage their own reputation in the best way. This implies that organizations should have the capacity to diagnose how their constituents perceive them, to configure an optimistic strategy for managing corporate reputation. For this, an organization needs to acknowledge 
the different dynamics of its environmental surroundings and learn who its key constituents are and what they want and expect from it (Preble, 2005). Reputation management has been described as a more active, centralised, focused and scientific approach to communicating with stakeholders (Fombrun, Gardberg \& Sever, 2000).

In regard to the evaluation of perceptions from different stakeholders, Reisnick (2004) points out that it is important to take into account the following:

- Identifying the areas of reputational risk to which they are exposed, by internal discussions, discussions with industry leaders, analysis of messages in the means of communication.

- Identifying the relevant stakeholders of the business, given the reputational context, and relating the areas of reputational risk with the relevant public.

- $\quad$ Establishing systems that evaluate the relative position of each group of critical stakeholders, from informal dialogue to rigorous proceedings based on surveys. It is also important to consider competitive and internal benchmarks to identify "better practices" (in this sense, collaborators can be a good source to identify reputational flaws).

- $\quad$ Prioritize the weak reputational areas and develop action plans to treat them and schedule continuous re-evaluations.

A greater knowledge of stakeholder perceptions about the organization will help define a sort of reputational platform where coherence and equilibrium between what the organization wants, can, or must do must be taken into account, as shown in Figure 1.

\section{Figure 1. Organization's reputational platform}

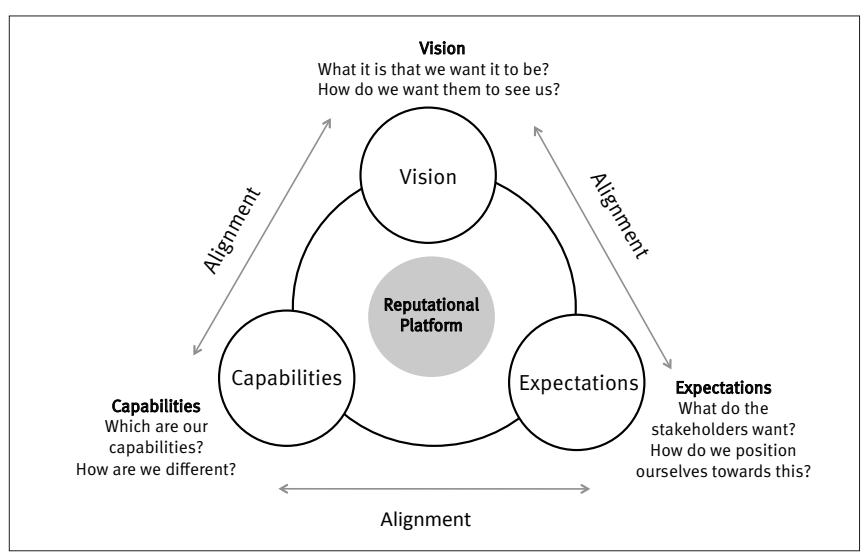

Thus, by identifying the sources of influence (direct or indirect) that may affect stakeholder perceptions, we have a consistent approach for measuring reputation through internal alignment and integration of the different areas that interact with different stakeholder groups (Georges, 2011). Hatch \& Schultz (2001) also established the importance of alignment between the vision, culture (capabilities) and image (expectations) of an organization in order to build a strong brand and solid reputation. Reputational gaps between internal and external stakeholders have immediate and long-term consequences, affecting future actions of stakeholders towards the organization. It may lead to the loss of trust (fundamental for business transactions), disengaged staff, and a wrongful orientation for the organization itself if it does not keep in touch with what the market expects from it (Smith, Smith, \& Wang, 2010, Mahon, 2002, Walker, 2010)

With these elements of analysis considered, an organization can determine whether it needs to reinforce its current position (if it already has a strong reputation), or work on the alignment of the aforementioned aspects: vision, culture (capabilities) and image (expectations). This will define the organization's strategic intent and allow for the development and implementation of a specific reputational strategy (Cornelissen, 2011). For example, Heugens, Van Riel, \& Van Den Bosch (2004) suggest four reputation management capabilities in response to reputational threats for the case of Dutch food firms, which eventually could be adapted to other similar cases of reputational risk in different contexts.

Argenti, Lytton-Hitchins \& Verity (2010) classified the possible alternatives for reputational strategy as follows:

- Excessive negligence (or business-as-usual): all actions are valid as long as prices are kept low, customers are satisfied and the quarterly expectations of shareholders are fulfilled. Between $25 \%$ and $30 \%$ of organizations in industrialized and emergent countries choose this strategy. Nevertheless, it is no longer considered viable because these organizations are very close to suffering irreparable damage to their reputation.

- Deceitful virtue: the "best face" is shown with the help of public relationships: changes in brand, philanthropy, sustainability programs and implementation of high-quality commercial practices. This attempts to build reputation as a forward-looking and responsible organization (even when this may not be true). A few organizations have implemented this strategy: the tobacco companies in the 6os; 
the pharmaceutical companies in the gos and some companies in 2000 (Enron). Nevertheless, this strategy is also unsustainable due to excessive exposure to competitors and potential litigations that can lead to losing the organization's operating licence.

- Favourable competition: the company emphasizes the responsible management of its reputation. It fulfils the required regulations, invests adequately in building its management capacities (health, security and environment) and corporate communications abilities. The organization concentrates in offering quality products and services, and in fulfilling its obligations with customers and shareholders. Reputation is not at the core of the organization, but firms invest in systems to manage this potential risk. Around $50 \%$ of enterprises match this category.

- Reliability as a competitive advantage: this strategy differentiates the organization from its competitors, attracts clients and employees, and allows the firm to obtain an excellent reputation among its multiple stakeholders. The organization is driven by its reputation, giving special attention to maintaining transparency and keeping its promises in all contexts. The search for trust is not an altruistic practice but an option for those organizations that desire to establish themselves in the market guided by an adequate management of its corporate reputation.

For many companies, working under the last strategy implies changing deeply rooted habits and training for new capacities. However, inside the new "Economy of Reputation", the management of reputation is a process that must begin from the inside, in order to effectively communicate the organization's identity. Gregory (2007) and Davies, Chun \& Kamin (2010) have stressed the importance of managing external reputation through internal reputation, involving the staff in the process of building a reputation that resonates within the organization. This is the reason why it is necessary to consider reputation management in every decision-making process of the organization and along all its different departments: managing reputational risk consists of providing the procedures and internal alignment necessary for detecting and minimizing those gaps that can potentially compromise the fulfilment of strategic goals.

Organizations do not position themselves just on the basis of good performance; this will also depend on how stakeholders conceptualize the organization's performance based on their perceptions and beliefs (Meyer, 2000, Bromley, 2000).
Corporate audiences rely on the reputations of firms for making investment decisions, career decisions and product choices (Melewar, 2003). Organizations that develop and potentiate their corporate reputation model and intangible management process inside horizontal strategic planning will guarantee their success, leadership and sustainability over the long term. As Casado, Méndiz, \& Peláez (2011) have pointed out, "the sustainability of a company must be described in terms of its capacity to accomplish its expectations and provide value to the public" (p. 3).

\section{MEASURING CORPORATE REPUTATION}

Although the concept of corporate reputation has already gone through decades of development, empirical literature's attempts to measure the construct haven't evolved at the same rate. Many times the constructs used to characterize corporate reputation do not cover all of its scope and conceptual richness. This gap needs to be addressed given that signalling perceptions of corporate reputation can often be problematic for firms: consumers are not always able to reliably capture the organization's position from its financial statements or annual reports. In this case, external signals of brand image (such as corporate reputation rankings) could provide value-relevant information to the market, as well as help organizations measure their performance from an outside perception (Sarstedt \& Schloderer, 2010, Smith, Smith, $\&$ Wang, 2010). The strategic management of reputation assumes that it is possible to measure the construct through time and improve its score. In this way the organization would be able to monitor the relationships between itself and its different stakeholders (Tkalac \& Vercic, 2007). Also, as Meyer (2000) states: "in order to move with confidence towards its vision, the organization must know how it is perceived and positioned today" (p. 81). An organization may measure its reputation over a period of time, usually for necessary credibility through an external auditor (WINSTON, 20002). A reg. ular tracking of an organization's stance on the reputational map can also help it identify potential issues (Carroll, 2011). Foreman \& Argenti's study (2005) cited several CEOs from diverse industries regarding their interest on reputational rankings; they all believed a firm benefited from the attention received through those surveys.

However, some of the main corporate reputation indexes that currently exist in the market present a biased nature. The source of bias can usually be tracked to the selection of respondents and selection of evaluation criteria. Most rank- 
ings lack a representative sample of stakeholders as respondents; they focus only on the perceptions of managers and business consultants. The items chosen are also mainly financial in nature, reflecting the nature of respondents. Therefore, most of them lack content validity by focusing only on those perceptions. In that sense, Walker (2010) establishes that reputation is stakeholder group-specific and issue-specific. He proposes that in order to measure reputation it should first be decided which interest group the organization wants to tackle, and on what issue it wants to assess reputation. This way he attempts to take into account the incompatibilities that emerge when comparing the perceptions of different stakeholders about a particular topic. It is necessary to decompose corporate reputation by issue and stakeholder: it may limit generalizability but it increases validity. Also, the instruments most commonly used do not have cross-cultural validity, which would allow for international comparability (Fombrun, Gardberg \& Sever, 2000, Mahon, 2002, Ponzi, Fombrun, \& Gardberg, 2011).

\section{Methodology of the Consumer Reputation Index}

The proposed CRI, attempts to incorporate these prior observations with the following steps:

\section{Sampling and measurement instrument}

First, it focuses on measuring corporate reputation on socially responsible issues. Second, it covers only a specific stakeholder group: 1500 consumers (those of legal age), whose characteristics are described in Table 1, of the six major cities of Peru, which taken together represent around $50 \%$ of the national population United Nations Population Fund [UNFPA] (2010) and $64.6 \%$ of the Peruvian GDP Instituto Nacional de Estadística e Informática [INEI] (2010). The instrument was completed on line, directly in a personal digital assistant by mean of random interception of people in the street. Every questionnaire took an average of 16-30 minutes. These prior considerations help avoid the potential pitfall of both, over representation and arbitrary weighting if more than one group has different scores for the seven reputation dimensions measured in this index. With these considerations taken into account the index attempts to address Walker's (2010) main qualm about measuring corporate reputation: define reputation for what and according to whom.
TABLE 1. Characteristics of the sample

\begin{tabular}{|c|c|c|c|}
\hline Variable & Groups & Frequency & $\%$ frequency \\
\hline \multirow{2}{*}{ Gender } & Male & 801 & $54 \cdot 3$ \\
\hline & Female & 699 & 46.6 \\
\hline \multirow{6}{*}{ Regions } & Lima & 435 & 29.1 \\
\hline & Chiclayo & 213 & 14.2 \\
\hline & Arequipa & 274 & 18.3 \\
\hline & Huancayo & 226 & 15.1 \\
\hline & Trujillo & 206 & 13.7 \\
\hline & Cusco & 146 & 9.7 \\
\hline \multirow{4}{*}{ Age } & $18-25$ & 372 & 24.8 \\
\hline & $26-35$ & 318 & 21.2 \\
\hline & $36-50$ & 461 & 30.7 \\
\hline & $51-80$ & 349 & 23.3 \\
\hline \multirow{5}{*}{ Qualification } & $\begin{array}{l}\text { Until primary } \\
\text { Until secondary }\end{array}$ & 39 & 2.6 \\
\hline & Higher non- & 366 & $24 \cdot 4$ \\
\hline & university & 338 & 22.5 \\
\hline & University Higher & 706 & 47.1 \\
\hline & Post-Graduate & 51 & 3.4 \\
\hline \multirow{4}{*}{$\begin{array}{l}\text { Socioeconomic } \\
\text { status }\end{array}$} & Upper class & 373 & 24.9 \\
\hline & Middle class & 344 & 22.9 \\
\hline & Lower class & 560 & 37.3 \\
\hline & Very low class & 223 & 14.9 \\
\hline
\end{tabular}

The index is composed of one main question regarding the respondent's overall perception of the organization (one that discretionally contributes to society's social, economic and environmental improvement, as quoted in the survey) and seven other constructs that characterize that organization's reputation issue: having good products and services, relationship with consumers, generates positive feelings, leadership and innovation, internal environment, ethical enterprise and discretional social responsibility practices. All of them were measured in a six-point multi-item Likert scale (1-absolutely agree, 6-absolutely disagree), according to each of their conceptual definitions described in Exhibit 2. These variables were chosen from an international literature review on reputational measurements and through the use of four local focus groups, to broaden and validate: (a) the level of understanding of the selected constructs, and (b) the spontaneous associations that arose from each of the constructs, creating new variable formulations in the process. Each focus group had six to eight people, between men and women, in the age range of 25-44. Two of them with a median income and the other two belonging to groups with high and low incomes, respectively. 
Exhibit 2 Model of questionary on line completed by respondents for the companies evaluated in the study

\section{ABOUT THE COMPANY: XXX}

We would like that you tell us, according to the following scale, how much you agree with the following statements about company XXX.

\begin{tabular}{|c|c|c|c|c|c|c|}
\hline & $\begin{array}{c}\text { ABSOLUTELY } \\
\text { DISAGREE }\end{array}$ & $\begin{array}{l}\text { DISAGREE } \\
\text { VERY MUCH }\end{array}$ & $\begin{array}{l}\text { SOMEWHAT } \\
\text { DISAGREE }\end{array}$ & $\begin{array}{c}\text { SOMEWHAT } \\
\text { AGREE }\end{array}$ & $\begin{array}{c}\text { AGREE } \\
\text { VERY } \\
\text { MUCH }\end{array}$ & $\begin{array}{c}\text { ABSOLUTELY } \\
\text { AGREE }\end{array}$ \\
\hline $\begin{array}{l}\text { IS A SOCIALLY RESPONSIBLE COMPANY } \\
\text { This company contributes actively and } \\
\text { voluntarily to the social improvement, } \\
\text { economic and the environmental of society. }\end{array}$ & 口 & 口 & 口 & 口 & 口 & 口 \\
\hline $\begin{array}{l}\text { IS A COMPANY THAT HAS GOOD PRODUCTS/ } \\
\text { SERVICES } \\
\text { This company stands behind its products and } \\
\text { services with good price and good quality } \\
\text { that meet consumer. }\end{array}$ & 口 & 口 & $\square$ & a & $\square$ & 口 \\
\hline $\begin{array}{l}\text { IS A COMPANY THAT RELATES WELL WITH } \\
\text { CONSUMERS (CUSTOMER ORIENTATION) } \\
\text { This company treats customers courteously, } \\
\text { communicates with them and takes care of } \\
\text { their safety and health. }\end{array}$ & 口 & 口 & $\square$ & 口 & $\square$ & 口 \\
\hline $\begin{array}{l}\text { IS A COMPANY THAT GENERATE POSITIVE } \\
\text { FELLINGS IN PEOPLE } \\
\text { This company generates respect, admiration } \\
\text { esteem and confidence. }\end{array}$ & $\square$ & $\square$ & $\square$ & 口 & $\square$ & 口 \\
\hline $\begin{array}{l}\text { IS A COMPANY WHIT LEADERSHIP AND } \\
\text { INNOVATION } \\
\text { This company is recognized, has excellent } \\
\text { leadership, is innovative, and seeks constant } \\
\text { overcoming. }\end{array}$ & 口 & 口 & 口 & 口 & 口 & 口 \\
\hline $\begin{array}{l}\text { IS A COMPANY WITH A GOOD WORKPLACE } \\
\text { ENVIRONMENT } \\
\text { This company looks like a good company to } \\
\text { work, already be by its infrastructure such as } \\
\text { its working environment, benefits and good } \\
\text { treats with its employees. }\end{array}$ & 口 & 口 & $\square$ & 口 & 口 & 口 \\
\hline $\begin{array}{l}\text { IS AN ETHICAL COMPANY } \\
\text { This company is a company with values that } \\
\text { obeys the laws, transparent and respects } \\
\text { people and the environment. }\end{array}$ & $\square$ & 口 & $\square$ & a & $\square$ & $\square$ \\
\hline $\begin{array}{l}\text { IS A COMPANY THAT PRACTICES SOCIAL } \\
\text { RESPONSIBILITY } \\
\text { This company supports good causes that } \\
\text { benefits society and environment. }\end{array}$ & 口 & 口 & $\square$ & 口 & 口 & 口 \\
\hline
\end{tabular}




\section{Reliability and validity of measures}

The logic behind CARI is the desirability measuring this multi-dimensional concept through its main features, which will subsequently be added to a single indicator score for each individual, as a factor analysis result. This form of analysis provides a better picture of the importance of each variable on the aggregate reputation index, the CRI, instead of creating an indicator based on the simple average of the Likert scale.

We followed De Vellis (2003) in his suggested procedure for scale development, so the data was first analysed in terms of internal consistency, items-test correlations, and factor anal- ysis procedures. Tables 3 and 4 report the results of the reliability test on the seven item-variables that are presumed to measure corporate reputation, statistics related to the convenience of performing a factor analysis, and the results of the exploratory factor analysis, respectively.

As Table 2 shows, Cronbach's a for the item-variables that comprise the CRI was 0.9721 , and these estimates largely exceed the threshold value of 0.7 as recommended by Nunnally (1978), suggesting strong internal consistency. In the same sense, the item-test correlation, item to total correlation and the average of inter-item covariance, all suggested that the variables are strongly correlated with each other and individually with the total scale.

\section{TABLE 2. Results of reliability analysis for the corporate reputation scale proposed}

\begin{tabular}{|c|c|c|c|c|}
\hline Item & $\begin{array}{l}\text { Item-test } \\
\text { correlation }\end{array}$ & $\begin{array}{l}\text { Item-total } \\
\text { correlation }\end{array}$ & $\begin{array}{l}\text { Inter-item } \\
\text { covariance }\end{array}$ & $\begin{array}{c}\text { Cronbach's } \\
a\end{array}$ \\
\hline Having good products and services & 0.9145 & 0.8828 & 1.186308 & 0.9686 \\
\hline Good relation with consumers & 0.9271 & 0.8998 & 1.178513 & 0.9674 \\
\hline Generating positive feelings in people & 0.9331 & 0.9078 & 1.173326 & 0.9669 \\
\hline Good workplace environment & 0.9214 & 0.8925 & 1.186635 & 0.9680 \\
\hline Practice standards in ethics & 0.9336 & 0.9083 & 1.171046 & 0.9668 \\
\hline Discretional social responsibility practices & 0.9221 & 0.8927 & 1.177318 & 0.9679 \\
\hline Test scale & & & 1.178885 & 0.9721 \\
\hline
\end{tabular}

The Kaiser-Meyer-Olkin measure of sampling adequacy (MSA) and Bartlett's test of Sphericity are showed in Table 3. Both statistics reported positive results. The MSA score of 0.953 and Bartlett's test of Sphericity were significant, deeming the data appropriate for factor analysis.

\section{TABLE 3. KMO and Barlett's test}

\begin{tabular}{l|l|l}
\hline Kaiser-Meyer-Olkin MSA & & $\mathbf{0 , 9 5 2 7}$ \\
\hline Bartlett's test of Sphericity & Approx. $x^{2}$ & 134000 \\
\hline & DF & 21 \\
\hline & Sig. & $<0,001$ \\
\hline
\end{tabular}

Finally, an exploratory factor analysis of the type of principal component analysis was applied to these seven item-variables describing the corporate's reputation in CSR. The results are reported in Table 4. This analysis allows us to asses measuring corporate reputation item-variables in one distinct unitary factor and to examine whether the item-variables loaded substantially on their hypothesis factors. In that sense, all seven item-variables had load factors over 0.60 and the first eigenvalue explained around 70 per cent of their variance, suggesting uni-dimensionality in their measure. This result confirmed Pearson and polychoric correlations between these seven item-variables and the main question of the survey regarding overall CSR perception. These correlations, shown in Table 5, were always higher than 0.6 and statistically significant due to its $p$-value $<0.01$. 
TABLE 4. Exploratory factor analysis

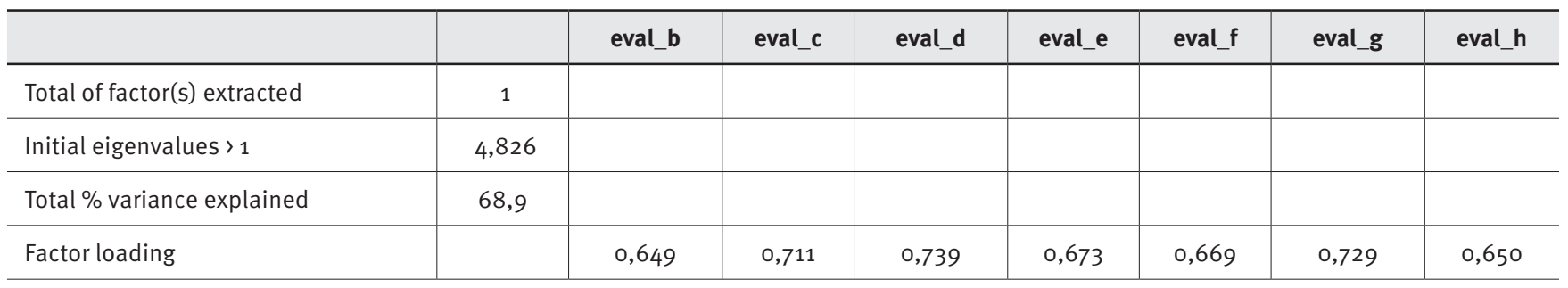

Note: Communalities of item-variables are equal to 1 since the extraction method was principal components.

TABLE 5. Pearson and polychoric correlations matrix

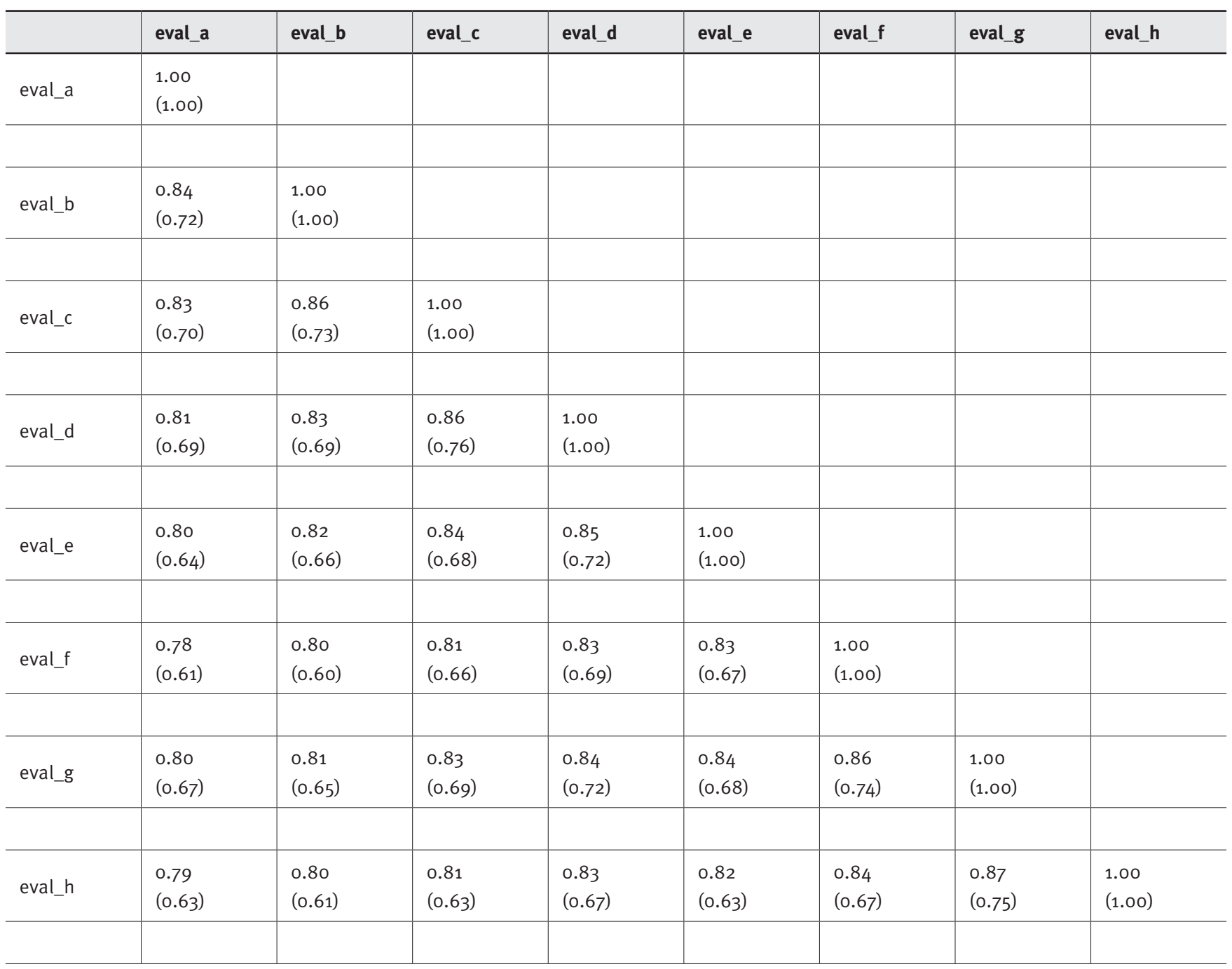

Note: Polychoric correlations in parentheses

\section{MAIN RESULTS OF CRI FOR 2012}

In this section we will review the advantages of the proposed index using the results obtained for 2012. The evaluated organizations were 69 Peruvian enterprises, representatives of 15 industrial sectors, according to Table 6. 
TABLE 6. Distribution of enterprises by industrial sectors

\begin{tabular}{l|c}
\hline Sector & Number of enterprises \\
\hline Public services & 4 \\
\hline Mining & 8 \\
\hline Department stores & 3 \\
\hline Combustibles & 4 \\
\hline Telephone & 3 \\
\hline Insurance & 4 \\
\hline Transportation & 4 \\
\hline Supermarkets & 4 \\
\hline Consumer goods & 6 \\
\hline Beverage & 4 \\
Bank & 7 \\
\hline Construction Materials & 5 \\
\hline Communications & 5 \\
\hline Beauty & 4 \\
\hline Food & 8 \\
\hline
\end{tabular}

It is worth mentioning that the survey included a question about the respondent's recollection of the organization's name. This was done in order to establish, not only which are the bestknown organizations in the Peruvian market, but also to identify whether there is a correlation between this construct and the reputation score given to a particular organization. Thus, the first relevant result from this new index is that the best-known organizations were not necessarily the ones that obtained the highest reputation scores.

When asked about the most important attribute of corporate reputation, both the general public and opinion leaders answered: "generating positive feelings in people". In contrast, one of the least important characteristics for corporate reputation was "having good products and services" (see Table 7).

\section{TABLE 7. Attributes ranking}

\begin{tabular}{l|c}
\hline Attributes & $\begin{array}{c}\text { General Public } \\
\text { Attribute Ranking }\end{array}$ \\
\hline Generating positive feelings in people & 1 \\
\hline Discretional social responsibility practices & 2 \\
\hline Good workplace environment & 3 \\
\hline Practice standards in ethics & 4 \\
\hline Good relation with consumers & 5 \\
\hline Having good products and services & 6 \\
\hline Leadership and innovation & 7 \\
\hline
\end{tabular}

The attributes that the Peruvian public values the most in organizations are not necessarily the same as those where they perceive organizations have a better performance. For example, although the general public considers that "discretional social responsibility practices" are important for a higher ranking in the index, it is also perceived as an attribute where organizations show a low performance (see Figure 2). The opposite happens with the attribute "leadership and innovation", perceived as the least important in the ranking by the public, but as the one where organizations show the best performance.

\section{Figure 2. General public's perception about organization's performance on the seven index attributes}

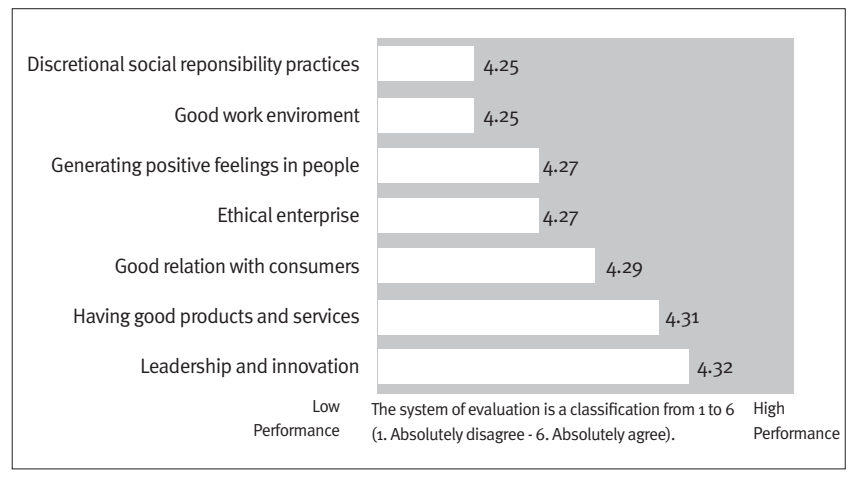

Figure 3 shows the economic sectors with the best reputation scores, on average: the media, food, and beauty sectors. The public services sector ranked last, followed by the mining and retail sectors.

\section{Figure 3. Average scores by economic sector}

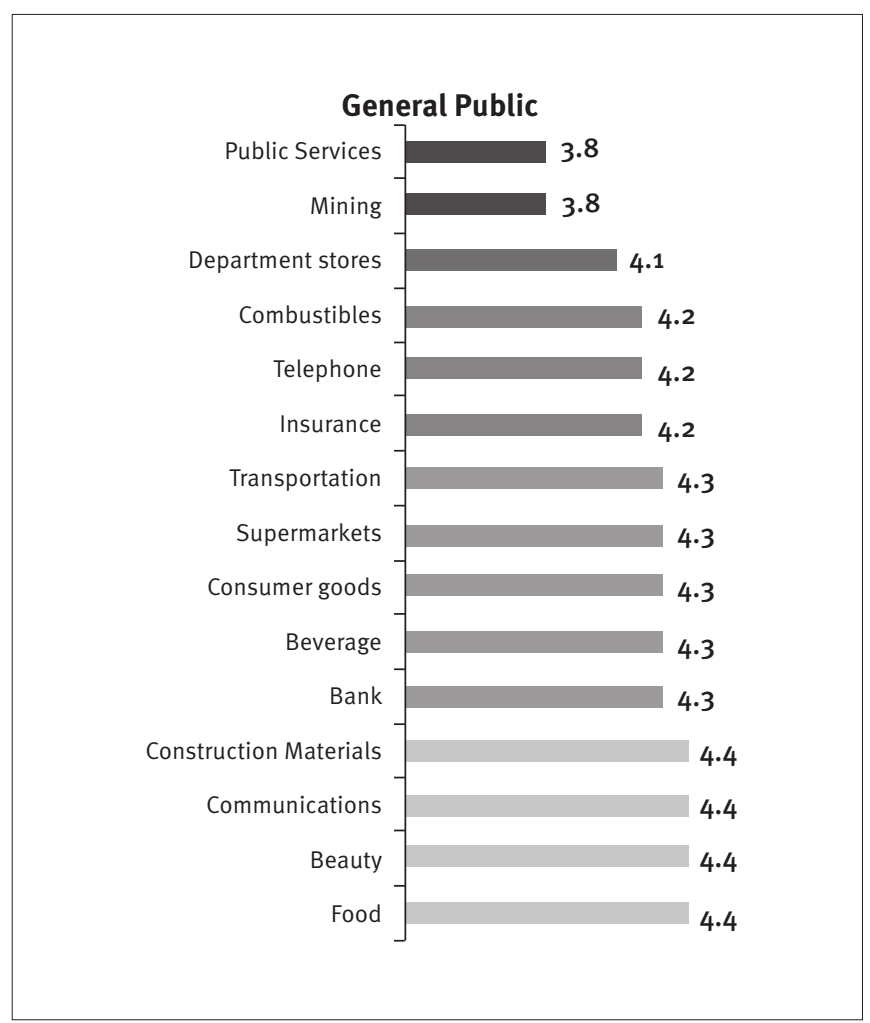


Finally, when classifying reputation scores by city of residence, respondents living in the jungle area gave higher scores to organizations than their counterparts living in the coast and highland areas. Age also influences assessment and ranking, given that elderly people (between 51 and 80 years old) tend to give higher reputation scores than younger people. The most critical age cohort is the one between 26 and 35 years, especially when evaluating the mining and services sectors. When comparing socioeconomic levels (SEL), sector A gave the highest scores in the index, whilst SEL D gave the lowest. Every SEL agreed in giving the lowest scores to retail, services and mining sectors. It is noteworthy that the food and media sectors always obtained the highest scores, regardless of the control variable taken into account.

\section{CONCLUSIONS}

The corporate reputation of an organization is now considered a key variable in improving the organization's attractiveness and its capacity for retention of both clients and investors. In that sense, this index seeks to be a managerial tool, which would allow the most important organizations to improve and strengthen their relationships with society in these keys dimensions examined.

The importance of having an index of this nature can be summarized as follows:

- It helps to annually monitor the effect of the organization's actions regarding corporate reputation.

- It identifies the best social responsibility practices taking the organization with the highest score as a benchmark.

- It identifies opportunities for improvement in each of the seven variables that characterize the corporate reputation of the organization in the CSR arena.

- It compares the performance of different sectors and organizations versus other sectors and competitors respectively. This means that it meets the needs of companies that need to know the perception of their management performance in order to compare with their peers and at the same time monitor the traceability of their impacts on the budgets in different countries and sectors in which they operate.

- It identifies opportunities for organizational improvement at different levels: city of origin, demographic variables, and lifestyle, because the quality of the data can deliver results at this level of detail.
Finally, new researches are needed if we want to fill the gap between what we know and understand about corporate reputation and the empirical developments we can build to measure it, but we could also take this fact as a confirmation that the meaning of the conceptual construct of corporate reputation does exist separately and regardless of our efforts to measure it.

\section{REFERENCES}

Argenti, P., Lytton-Hitchins, J., \& Verity, R. (2010). The good, the bad, and the trustworthy. Strategy+Business, 61. Retrieved from: http://www. strategy-business.com/media/file/sb61_10401.pdf.

Awang, Z., \& Jusoff, K. (2009). The effects of corporate reputation on the competitiveness of Malaysian telecommunication service providers. International Journal of Business and Management, 4 (5), 173-178.

Baden-Fuller, C., \& Hwee, S. (2001). Building reputations: the role of alliances in the European Business School scene. Long Range Planning, 34 (6), 741-755.

Balmer, J. M. T., \& Greyser, S. A. (2002). Managing the multiple identities of the corporation. California Management Review, 44 (3), 72-86.

Barnett, M. L., Jermier, J. M., \& Lafferty, B. A. (2006). Corporate reputation: the definitional landscape. Corporate Reputation Review, 9 (1), 26-38.

Barney, J. (1991). Firm resources and sustained competitive advantage. Journal of Management, 17 (1) 99-120.

Baur, D., \& Schmitz, H. P. (2011). Corporations and NGOs: when accountability leads to co-optation. Journal of Business Ethics, 106 (1), 9-21.

Berens, G. (2004). Corporate branding: the development of corporate associations and their influence on stakeholder reaction. Doctoral dissertation, Erasmus University Rotterdam. Rotterdam, Netherlands.

Berens, G., \& Van Riel, C. (2004). Corporate associations in the academic literature: three main streams of thought in the reputation measurement literature. Corporate Reputation Review, 7 (2), 161-178.

Brammer, S., \& Millington, A. (2005). Corporate reputation and philanthropy: an empirical analysis. Journal of Business Ethics, 61 (1), 29-44.

Bromley, D. (2000). Psychological aspects of corporate identity, image and reputation. Corporate Reputation Review, 3 (3), 240-252.

Brown, T. J., Dacin, P. A., Pratt, M. G., \& Whetten, D. (2006). Identity, intended image, construed image, and reputation: an interdisciplinary framework and suggested terminology. Journal of the Academy of Marketing Science, 34 (2), 99-106.

Casado, A, Méndiz., A, \& Peláez, J. (2011). Nuevos retos en la gestión de la reputación corporativa. Del director de comunicación al chief reputation officer. Presentation at the III Congreso Internacional Latina de Comunicación Social, Universidad de La Laguna. San Cristóbal de La Laguna, Spain. Retrieved from: http://www.revistalatinacs.org/11SLCS/ actas_2011_IIICILCS/093_Casado.pdf.

Chernatony, L. (1999). Brand management through narrowing the gap between brand identity and brand reputation. Journal of Marketing Management, 15 (1-3), 157 -179. 
Cornelissen, J. (2011). Corporate communication: a guide to theory and practice. 3rd Edition. London: Sage Publications Ltd.

Covey, J., \& Brown, D. (2001). Critical cooperation: an alternative form of civil society-business engagement. IDR Reports, 17 (1), 1-18.

Davies, G, Chun., R, \& Kamins, M. A. (2010). Reputation gaps and the performance of service organizations. Strategic Management Journal, 31 (5), 530-546.

De Vellis, R. F. (2003). Scale development: theory and applications. 2nd ed. Applied Social Research. Methods Series. Thousand Oaks, CA: Sage.

Deephouse, D. L., \& Carter, S. M. (2005). An examination of differences between organizational legitimacy and organizational reputation. Journal of Management Studies, 42 (2), 329-360.

Einwiller, S. A., Carroll, C. E, \& Korn, K. (2010). Under what conditions do the news media influence corporate reputation? The roles of media dependency and need for orientation. Corporate Reputation Review, 12 (4), 299-315.

European Communication Monitor. (2011). Empirical Insight into Strategic Communication in Europe-Results of a Survey of 43 Countries. Retrieved from: www.communicationmonitor.eu. Brussels: European Public Relations Education and Research Association.

Fombrun, C. J. (1996). Reputation: realizing value from the corporate image. Boston: Harvard Business School Press.

Fombrun, C., \& Van Riel, C. (1997). The reputational landscape. Corporate Reputation Review, 1 (1-2), 5-13.

Fombrun, C. J., Gardberg, N. A., \& Sever, J. M. (2000). The reputation quotient: a multi-stakeholder measure of corporate reputation. Journal of Brand Management, 7 (4), 241-255.

Fombrun, C. (2011). Reputations, roller coasters, and wild rides on wall street. Cartel sesión presented at Primera Conferencia Latinoamericana de Reputación Corporativa. Cartagena, Colombia. Octubre.

Foreman, J., \& Argenti, P. A. (2005). How corporate communication influences strategy implementation, reputation and the corporate brand: an exploratory qualitative study. Corporate Reputation Review, 8 (3), 245-264.

García de los Salmones, M, Herrero, A., \& Rodríguez del Bosque, I. (2005). Influence of corporate social responsibility on loyalty and valuation of services. Journal of Business Ethics, 61 (4), 369-385.

Gardberg, N., \& Fombrun, C. (2002). The Global Reputation Quotient Project: First steps towards a cross-nationally valid measure of corporate reputation. Corporate Reputation Review, 4 (4), 303-307.

Georges, N. (2011). Working strategically with reputation management. Cartel sesión presented at Primera Conferencia Latinoamericana de Reputación Corporativa, Cartagena, Colombia. October.

Gotsi, M., \& Wilson, A. (2001). Corporate reputation: seeking a definition. Corporate Communications: An International Journal, 6 (1), 24-30.

Gregory, A. (2007). Involving stakeholders in developing corporate brands: the communication dimension. Journal of Marketing Management, 23 (1-2), 59-73.

Hatch, M. J., \& Schultz, M. (1997). Relations between organizational culture, identity and image. European Journal of Marketing, 31 (5-6), $356-365$.

Hatch, M. J., \& Schultz, M. (2001). Are the strategic stars aligned for your corporate brand? Harvard Business Review, 79 (2), 128-34.
Huang, Y-H. (2008). Trust and relational commitment in corporate crises: the effects of crisis communicative strategy and form of crisis response. Journal of Public Relations Research, 20 (3), 297-327.

Instituto Nacional de Estadística e Informática. (2009). Producto Bruto Interno por Departamentos. Retrieved from: http://www.slideshare.net/ empresarioshaciendopais/producto-bruto-interno-por-departamentos.

Karaosmanoglu, E., \& Melewar, T. C. (2006). Corporate communications, identity and image: a research agenda. Journal of Brand Management, 14 (1-2), 196-206.

Kitchen, P., \& Laurence, A. (2003). Corporate reputation: an eight-country analysis. Corporate Reputation Review, 6 (2), 103-117.

Mahon, J. F., \& Wartick, S. L. (2003). Dealing with stakeholders: how reputation, credibility and framing influence the game. Corporate Reputation Review, 6 (1), 19-35.

Mahon, J. F. (2002). Corporate reputation: a research agenda using strategy and stakeholder literature. Business \& Society, 41 (4), 415-445.

Martin, G, Beaumont, P., Doig, R., \& Pate, J. (2005). Branding: a new performance discourse for HR? European Management Journal, 23 (1), 76-88.

Martínez, I., \& Olmedo, I. (2009). La medición de la reputación empresarial: problemática y propuesta. Investigaciones europeas de dirección y economía de la empresa, 15 (2), 127-142.

Meijer, M., \& Kleinnijenhuis, J. (2006). Issue news and corporate reputation: applying the theories of agenda setting and issue ownership in the field of business communication. Journal of Communication, 56 (3), 543-559.

Melewar, T. C. (2003). Determinants of the corporate identity construct: a review of the literature. Journal of Marketing Communications, 9 (4), 195-220.

Melewar, T. C., Karaosmanoglu, E., \& Paterson, D. (2005). Corporate identity: concept, components and contribution. Journal of General Management, 31 (1), 59-81.

Meyer, S. (2000). Currency of character: unlocking the energy source of reputation. Corporate Reputation Review, 3 (1), 81-82.

Nunnally, J. C. (1978). Psychometric theory. 2nd ed. New York, NY: McGraw-Hill.

Ponzi, L., Fombrun, C., \& Gardberg, N. (2011). RepTrak ${ }^{\mathrm{TM}}$ pulse: conceptualizing and validating a short-form measure of corporate reputation. Corporate Reputation Review, 14 (1), 15-35.

Porter, M., \& Kramer, P. (2006). Strategy and society: the link between competitive advantage and corporate social responsibility. Harvard Business Review, 84 (12), 78-92.

Prado, F. (2008). Las 50 empresas más admiradas según Reputation Institute. Ser Responsable en el Siglo XXI, 2 (16), 30-32.

Preble, J. F. (2005). Toward a comprehensive model of stakeholder management. Business and Society Review, 110 (4), 407-431.

Pruzan, P. (2001). Corporate reputation: image and identity. Corporate Reputation Review, 4 (1), 50-64.

Heugens, P., Van Riel, C., \& Van Den Bosch, F. (2004). Reputation management capabilities as decision rules. Journal of Management Studies, 41 (8), 1349-1377.

Resnick, J. (2004). Corporate reputation: managing corporate reputation - applying rigorous measures to a key asset. The Journal of Business Strategy, 25 (6), 30-38. 
Roberts, P., \& Dowling, G. (2002). Corporate reputation and sustained superior financial performance. Strategic Management Journal, 23 (12), 1077-1093.

Roper, S., \& Fill, C. (2012). Corporate reputation: brand and communication. Essex: Pearson Education Limited.

Sarstedt, M., \& Schloderer, M. P. (2010). Developing a measurement approach for reputation of non-profit organizations. International Journal of Nonprofit \& Voluntary Sector Marketing, 15 (3), 276-299.

Schultz, M., Hatch, M. J., \& Larsen, M. H. (2000). The expressive organisation: linking identity, reputation, and corporate brand. Oxford, UK: Oxford University Press.

Smith, K. T, Smith, M., \& Wang, K. (2010). Does brand management of corporate reputation translate into higher market value? Journal of Strategic Marketing, 18 (3), 201-221.
Steyn, B. (2003). From strategy to corporate communication strategy: a conceptualisation. Journal of Communication Strategy, 8 (2), 168-183.

Tkalac, A., \& Vercic, D. (2007). Reputation as matching identities and images: extending Davies and Chun's (2002) research on gaps between the internal and external perceptions of the corporate brand. Journal of Marketing Communications, 13 (4), 277-290.

United Nations Population Fund (2010). Perú: población estimada y proyectada, según departamentos, 1990 - 2015. Retrieved from: http:// www.unfpa.org.pe/infosd/poblacion/poblacion_05.htm.

Walker, K. A. (2010). A systematic review of the corporate reputation literature: definition, measurement, and theory. Corporate Reputation Review, 12 (4), 357-387.

Winn, M. I., Macdonald, P., \& Zietsma, C. (2008). Managing industry reputation: the dynamic tension between collective and competitive reputation management strategies. Corporate Reputation Review, 11 (1), 35-55. 